\title{
Enhancement of antinociception by coadminstration of minocycline and a non-steroidal anti-inflammatory drug indomethacin in naïve mice and murine models of LPS-induced thermal hyperalgesia and monoarthritis
}

\author{
Ala'a Ahmed Abu-Ghefreh, Willias Masocha*
}

\begin{abstract}
Background: Minocycline and a non-steroidal anti-inflammatory drug (NSAID) indomethacin, have antiinflammatory activities and are both used in the management of rheumatoid arthritis. However, there are no reports on whether coadministration of these drugs could potentiate each other's activities in alleviating pain and weight bearing deficits during arthritis.

Methods: LPS was injected to BALB/C mice intraperitoneally (i.p.) to induce thermal hyperalgesia. The hot plate test was used to study thermal nociception in naive BALB/C and C57BL/6 mice and BALB/c mice with LPS-induced thermal hyperalgesia and to evaluate antinociceptive effects of drugs administered i.p. Monoarthritis was induced by injection of LPS intra-articularly into the right hind (RH) limb ankle joint of C57BL/6 mice. Weight bearing changes and the effect of i.p. drug administration were analyzed in freely moving mice using the video-based CatWalk gait analysis system.

Results: In naïve mice indomethacin ( 5 to $50 \mathrm{mg} / \mathrm{kg}$ ) had no significant activity, minocycline (25 to $100 \mathrm{mg} / \mathrm{kg}$ ) produced hyperalgesia to thermal nociception, however, coadministration of minocycline $50 \mathrm{mg} / \mathrm{kg}$ with indomethacin 5 or $10 \mathrm{mg} / \mathrm{kg}$ produced significant antinociceptive effects in the hot plate test. A selective inhibitor of COX-1, FR122047 (10 mg/kg) and a selective COX-2 inhibitor, CAY10404 (10 mg/kg) had no significant antinociceptive activities to thermal nociception in naïve mice, however, coadministration of minocycline, with CAY10404 but not FR122047 produced significant antinociceptive effects. In mice with LPS-induced hyperalgesia vehicle, indomethacin $(10 \mathrm{mg} / \mathrm{kg})$ or minocycline $(50 \mathrm{mg} / \mathrm{kg})$ did not produce significant changes, however, coadministration of minocycline plus indomethacin resulted in antinociceptive activity. LPS-induced RH limb monoarthritis resulted in weight bearing ( $\mathrm{RH} / \mathrm{left}$ hind $(\mathrm{LH}) \mathrm{limb}$ paw pressure ratios) and $\mathrm{RH} / \mathrm{LH}$ print area ratios deficits. Treatment with indomethacin $(1 \mathrm{mg} / \mathrm{kg})$ or minocycline $(50 \mathrm{mg} / \mathrm{kg})$ had no effects on the weight bearing and print area ratios deficits of monoarthritic mice. However, combination of minocycline plus indomethacin restored weight bearing and paw print area ratios of monoarthritic mice similar to that observed in non-arthritic control mice.
\end{abstract}

Conclusions: Coadministration of indomethacin or a selective COX-2 inhibitor, CAY10404 with minocycline potentiates their effects and results in antinociception against thermal nociception, reduction of thermal hyperalgesia and alleviation of weight bearing deficits in monoarthritic mice at doses where either drug alone

\footnotetext{
* Correspondence: masocha@hsc.edu.kw

Department of Applied Therapeutics, Faculty of Pharmacy, Kuwait University,

P.O. Box 24923 Safat, 13110 Kuwait
} 


\section{Background}

Minocycline, a second-generation semisynthetic tetracycline antibiotic, has pleiotropic biologic activities besides its antimicrobial activities. Apart from its use as an antibiotic it is used in the management of various inflammatory diseases such as rheumatoid arthritis, periodontitis and several dermatological conditions [1]. In the management of rheumatoid arthritis minocycline is used as a disease-modifying antirheumatic drug (DMARD) and it alleviates joint tenderness and swelling among other features of the disease [2-5].

Recently, interest has arisen on its possible use in the management of pain. Research has been mostly on neuropathic pain where it has been shown that preemptive treatment with minocycline has protective effects but is ineffective once pain has developed [6,7]. It has also been reported to have antinociceptive effects in various models of inflammatory pain such as the formalininduced nociception test and its antinociceptive effects have been suggested to be more of an anti-inflammatory nature rather than a centrally acting analgesic [8].

In this study the antinociceptive effects of co-administration of minocycline with a non-steroidal antiinflammatory drug (NSAID), indomethacin, a selective inhibitor of COX-1, FR122047 or a selective COX-2 inhibitor, CAY10404, were evaluated in naïve mice and mice with lipopolysaccharide (LPS)-induced thermal hyperalgesia and monoarthritis. LPS is an endotoxin from gram-negative bacterial cell wall, which when administered intra-articularly into the ankle joint of a rodent limb can induce arthritis $[9,10]$. When the endotoxin is administered intraperitoneally it can cause generalized hyperalgesia. Various mechanisms are purported to be responsible for the LPS-induced hyperalgesia including the release and activation of proinflammatory cytokines and gelatinases, as well as glial cell activation [11-15]. Cytokines such as TNF- $\alpha$ and IL$1 \beta$ cause the release of nociceptive mediators such as prostaglandins and sympathetic amines which lower the nociceptive threshold of sensory nerves [16-19]. Indomethacin is used in the treatment of various inflammatory diseases such as rheumatoid arthritis, osteoarthritis, gout, and ankylosing spondylitis [20-23]. NSAIDs are a heterogenous group of drugs commonly used in the management of inflammatory pain [24-27]. They produce their basic analgesic effect via inhibition of cyclooxygenase (COX) enzymes [25-27]. The analgesic effects of NSAIDs are also due to a number of mechanisms including a central mechanism involving both prostaglandin synthesis inhibition and probably changes in the endocannabinoid and monoaminergic system [28-32].

\section{Methods}

Animals

BALB/c $(\mathrm{n}=338)$ and C57BL/6 $(\mathrm{n}=32)$ mice (8 to 12 weeks old; 20 - $30 \mathrm{~g}$ ) were used and were supplied by the breeding unit at the Health Sciences Center, Kuwait University, Kuwait, and were kept in temperature controlled $\left(24 \pm 1^{\circ} \mathrm{C}\right)$ rooms with food and water ad libitum. All experiments were performed during the same period of the day (8:00 AM to 4:00 PM) to exclude diurnal variations in pharmacological effects. The animals were handled in compliance with European Communities Council Directive 86/609 for the care of laboratory animals and ethical guidelines for research in experimental pain with conscious animals [33]. All procedures were approved by the Kuwait University Health Sciences Center animal care committee.

\section{Drug treatment and assessment of thermal nociception}

Minocycline and indomethacin (up to $10 \mathrm{mg} / \mathrm{kg}$ ) (SigmaAldrich, St Louis, MO, USA) were dissolved in phosphate buffered saline (PBS). Indomethacin ( $\geq 20 \mathrm{mg} / \mathrm{kg}$ ) (SigmaAldrich, USA)), selective COX-1 inhibitor, FR122047 [34,35] and selective COX-2 inhibitor, CAY10404 [36] (both from Cayman Chemical, Ann Arbor, MI, USA) were dissolved in peanut oil (Sigma-Aldrich, USA).

$\mathrm{BALB} / \mathrm{c}$ or $\mathrm{C} 57 \mathrm{BL} / 6$ mice were treated intraperitoneally (i.p.) with minocycline, indomethacin, FR122047, CAY10404 or their vehicles at a volume of $5 \mu \mathrm{l} / \mathrm{g}$ body mass. For the evaluation of coadministration, mice received two separate i.p. injections at the same time: minocycline + indomethacin, minocycline + FR122047, minocycline + CAY10404, minocycline + vehicle for indomethacin, minocycline + vehicle for FR122047, minocycline + vehicle for CAY10404, indomethacin + vehicle for minocycline, FR122047 + vehicle for minocycline or CAY10404 + vehicle for minocycline.

Thermal hyperalgesia was induced by administering LPS (Sigma-Aldrich, St Louis, MO, USA) at $1 \mathrm{mg} / \mathrm{kg}$ at a volume of $5 \mu \mathrm{l} / \mathrm{g}$ body mass. Reaction latency to the hot plate were measured before LPS administration and over a period of 1 month after LPS administration. Mice were treated intraperitoneally with drugs on the seventh day after LPS inoculation based on thermal hyperalgesia results (see Results section) and the effects of drug treatment on LPS-induced thermal hyperalgesia evaluated. 
Reaction latencies to hot plate test were measured before (baseline latency) and at various times starting at 30 minutes after drug treatment. Briefly, mice were individually placed on a hot plate (Panlab SL, Barcelona, Spain) with the temperature adjusted to $55 \pm 1{ }^{\circ} \mathrm{C}$. The time to the first sign of nociception, paw licking, flinching or jump response to avoid the heat was recorded and the animal immediately removed from the hot plate. A cut-off period of 20 seconds was maintained to avoid damage to the paws.

\section{Induction of monoarthritis and evaluation of changes in weight bearing and paw print area}

Inflammatory monoarthritis was induced as described previously $[9,10]$. Briefly, mice were anaesthetized with halothane and LPS $10 \mu \mathrm{g}$ in $20 \mu \mathrm{l}$ PBS was injected intra-articularly into the right hind limb ankle joint through the Achilles tendon using a 301/2-gauge needle. PBS $(20 \mu \mathrm{l})$ was administered in the same way to the control group. The mice were made to cross the Catwalk walkway before LPS-inoculation and at 2 days post-LPS inoculation as described previously [10].

Mice were treated intraperitoneally with indomethacin 1 and $10 \mathrm{mg} / \mathrm{kg}$, minocycline $(50 \mathrm{mg} / \mathrm{kg})$ alone, both drugs at the same time or their vehicles on the second day after LPS inoculation based on the weight bearing results [10]. The mice were then made to cross the Catwalk walkway at 1 hour post-drug treatment.

Paw pressure intensity and print areas of freely moving animals were measured using the Catwalk gait analysis system (Noldus Information Technology, The Netherlands) as described previously [10,37]. Briefly, the CatWalk instrument consists of an enclosed walkway with a glass plate, a high speed colour camera, and a recording and analysis software to assess the locomotor performance of rodent models. Each mouse was placed individually in the CatWalk walkway and allowed to walk freely and traverse from one side to the other of the walkway glass plate. The recordings were carried out when the room was completely dark, except for the light from the computer screen. Light from a fluorescent lamp was emitted inside the glass plate and completely internally reflected. Where the mouse paws made contact with the glass plate, light was reflected down and the illuminated contact areas recorded with a high speed colour video camera that was positioned underneath the glass plate connected to a computer that runs the CatWalk software 7.1. The software automatically labelled all the areas containing pixels above the set threshold (7 pixels). These areas were identified and assigned to the respective paws. Analysis of the recording generated a wide range of parameters of which only paw pressure (light intensity, which is the mean brightness of all pixels of the print at maximum paw contact, ranging from 0-255 arbitrary units) and paw print area (complete surface area contacted by the paw during a stance phase) were analysed.

\section{Data analysis}

The results in the text and figures are expressed as the means \pm S.E.M. For the hot plate test percentage of change from baseline latency was calculated as follows: for naïve mice (response latency after drug treatment baseline latency)/baseline latency $\times 100$ and for mice with LPS-induced hyperalgesia (response latency after drug treatment - latency before drug treatment at 7 days post LPS inoculation)/latency before drug treatment at 7 days post LPS inoculation $\times 100$. For the Catwalk gait analysis weight bearing was measured as the right hind $(\mathrm{RH}) /$ left hind $(\mathrm{LH})$ limb ratio of the light intensity and the print area ratio was obtained from the $\mathrm{RH} / \mathrm{LH}$ print areas. Percentage of change after drug treatment was calculated as follows: (light intensity or print area ratio after drug treatment - light intensity or print area ratio before drug treatment at 2 days post LPS inoculation)/light intensity or print area ratio before drug treatment at 2 days post LPS inoculation $\times 100$. Statistical analyses were performed using two-way analysis of variance (ANOVA) followed by Bonferroni posttests or one-way ANOVA followed by Newman-Keuls multiple comparison test. The differences were considered significant at $\mathrm{p}<0.05$.

\section{Results}

Effect of treatment with indomethacin, minocycline or coadministration of minocycline plus indomethacin in a hot plate test in naïve $\mathrm{BALB} / \mathrm{C}$ and $\mathrm{C} 57 \mathrm{BL} / 6$ mice

The administration of indomethacin (5 to $50 \mathrm{mg} / \mathrm{kg}$ intraperitoneally) to naïve $\mathrm{BALB} / \mathrm{c}$ mice did not result in a significant change in reaction latency compared to baseline latency in the hot plate at $55^{\circ} \mathrm{C}$ compared to vehicle treatment (Figure 1 and Table 1 ). The administration of minocycline $50 \mathrm{mg} / \mathrm{kg}$ (this dose has been used previously in other pain studies $[6,8]$ ) intraperitoneally to $\mathrm{BALB} / \mathrm{c}$ mice produced a time dependent reduction in reaction latency in the hot plate at $55^{\circ} \mathrm{C}$ (Figure 1). The reaction latency fell from a baseline latency of $12.66 \pm 0.42 \mathrm{~s}$ to $8.31 \pm 0.60 \mathrm{~s}$ at 1 hour post minocycline administration and by 2 hours it had returned to baseline reaction latency. The minocyclineinduced reduction of reaction latency time from baseline value was dose dependent (Table 1 ). However, the coadministration of indomethacin 5 or $10 \mathrm{mg} / \mathrm{kg}$ and minocycline $50 \mathrm{mg} / \mathrm{kg}$ resulted in an increase in the reaction latency time compared to vehicle treated animals or indomethacin or minocycline alone (Figure 1 and Table 1). The effects of indomethacin $10 \mathrm{mg} / \mathrm{kg}$, minocycline $50 \mathrm{mg} / \mathrm{kg}$ or coadministration of the two 


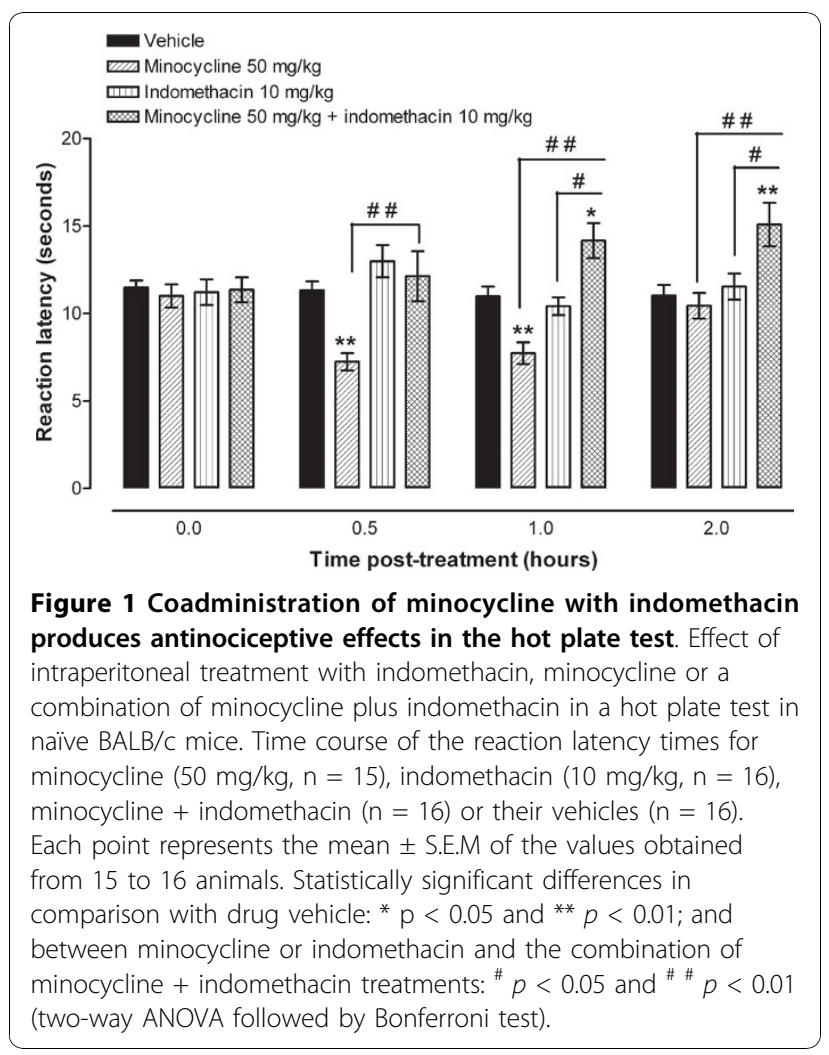

drugs on reaction latency was also tested in another mouse strain, C57BL/6, with similar results (Table 2). In order to determine the role of specific COX isoenzyme inhibition on this potentiated antinociceptive effects, minocycline was coadministered with selective COX inhibitors. The administration of a selective inhibitor of COX-1, FR122047 (10 mg/kg intraperitoneally) or a selective inhibitor of COX-2, CAY10404 $(10 \mathrm{mg} / \mathrm{kg}$ intraperitoneally) to $\mathrm{BALB} / \mathrm{c}$ did not result in a significant change in reaction latency compared to baseline latency in the hot plate or compared to vehicle treatment (Table 3). The coadministration of minocycline 50 $\mathrm{mg} / \mathrm{kg}$ and FR122047 $10 \mathrm{mg} / \mathrm{kg}$ did not significantly change the reduced reaction latency caused by minocycline $(p>0.05$, Table 3$)$. However, the coadministration of minocycline $50 \mathrm{mg} / \mathrm{kg}$ and CAY10404 $10 \mathrm{mg} / \mathrm{kg}$ resulted in a significant increase in reaction latency $(p<$ 0.01 ) at 1 hour post treatment compared to vehicle or minocycline alone, respectively (Table 3 ).

Effect of treatment with indomethacin, minocycline or coadministration of minocycline plus indomethacin in a hot plate test in BALB/C mice with LPS-induced thermal hyperalgesia

Inflammatory hyperalgesia to thermal nociception was induced in BALB/c mice by a single i.p. administration

Table 1 Percentage of change from baseline reaction latency of BALB/c mice at 1 hour post-drug treatment in the hot plate test

\begin{tabular}{|c|c|c|}
\hline $\begin{array}{l}\text { Drug and dose administered to } \\
\text { mice }\end{array}$ & $\begin{array}{l}\% \text { Change in reaction latency (mean } \pm \text { S.E.M of the values obtained from } 6 \text { to } \\
16 \text { animals.) }\end{array}$ & $\begin{array}{c}\text { Statistical } \\
\text { significance }\end{array}$ \\
\hline Vehicle for indomethacin & $-4.64 \pm 4.619(n=7)$ & \\
\hline Indomethacin $5 \mathrm{mg} / \mathrm{kg}$ & $-10.43 \pm 4.11(n=7)$ & ns \\
\hline Indomethacin 10 mg/kg & $-1.02 \pm 3.85(n=7)$ & ns \\
\hline Indomethacin 20 mg/kg & $-6.43 \pm 5.75(n=7)$ & ns \\
\hline Indomethacin 50 mg/kg & $2.03 \pm 10.29(n=7)$ & ns \\
\hline Vehicle for minocycline & $-5.34 \pm 2.68(n=16)$ & \\
\hline Minocycline 12.5 mg/kg & $-6.78 \pm 3.09(n=11)$ & ns \\
\hline Minocycline 25 mg/kg & $-21.63 \pm 2.24(n=11)$ & $* *$ \\
\hline Minocycline 50 mg/kg & $-34.16 \pm 4.31(n=10)$ & $* *$ \\
\hline Minocycline 100 mg/kg & $-34.21 \pm 4.08(n=8)$ & $* *$ \\
\hline $\begin{array}{l}\text { Vehicles for indomethacin and } \\
\text { minocycline }\end{array}$ & $-4.97 \pm 2.51(n=16)$ & \\
\hline $\begin{array}{l}\text { Indomethacin } 5+\text { minocycline } 50 \\
\mathrm{mg} / \mathrm{kg}\end{array}$ & $21.49 \pm 4.70(n=6)$ & $* *$ \\
\hline $\begin{array}{l}\text { Indomethacin } 10+\text { minocycline } 50 \\
\mathrm{mg} / \mathrm{kg}\end{array}$ & $24.567 \pm 4.05(n=16)$ & $* *$ \\
\hline $\begin{array}{l}\text { Indomethacin } 10+\text { minocycline } 25 \\
\mathrm{mg} / \mathrm{kg}\end{array}$ & $-7.65 \pm 4.97(n=6)$ & ns \\
\hline
\end{tabular}


Table 2 Percentage of change from baseline reaction latency times of C57BL/6 mice at 1 hour post-drug treatment in the hot plate test

\begin{tabular}{|c|c|c|}
\hline $\begin{array}{l}\text { Drug and dose administered to } \\
\text { mice }\end{array}$ & $\begin{array}{l}\% \text { Change in reaction latency (mean } \pm \text { S.E.M of the values obtained from } 7 \text { to } 9 \\
\text { animals.) }\end{array}$ & $\begin{array}{c}\text { Statistical } \\
\text { significance }\end{array}$ \\
\hline $\begin{array}{l}\text { Vehicles for indomethacin and } \\
\text { minocycline }\end{array}$ & $-8.62 \pm 5.65(n=7)$ & \\
\hline Indomethacin 10 mg/kg & $3.25 \pm 6.05(n=8)$ & ns \\
\hline Minocycline 50 mg/kg & $-34.85 \pm 3.88(n=8)$ & $* *$ \\
\hline $\begin{array}{l}\text { Indomethacin } 10+\text { minocycline } 50 \\
\mathrm{mg} / \mathrm{kg}\end{array}$ & $32.74 \pm 10.85(n=9)$ & $* *$ \\
\hline
\end{tabular}

\# (response latency after drug treatment - baseline latency)/baseline latency $\times 100$.

${ }^{\S}$ Statistically significant differences in comparison with drug vehicle: ${ }^{*} p<0.01$; ns: no statically significant differences in comparison with drug vehicle (one-way ANOVA followed by Newman-Keuls test).

of an endotoxin, lipopolysaccharide (LPS, $1 \mathrm{mg} / \mathrm{kg}$ ), dissolved in PBS. A significant reduction in response latency time to thermal stimuli compared to the baseline latency in the hot plate test was observed in LPS-inoculated mice from 4 to 14 days post inoculation (Figure 2).

Mice with LPS-induced hyperalgesia to thermal nociception at 7 days post inoculation (Figure 3A) were treated with indomethacin, minocycline or minocycline plus indomethacin coadminstration and their reaction latency to the hot plate recorded.

The administration of indomethacin $(10 \mathrm{mg} / \mathrm{kg})$ or minocycline $(50 \mathrm{mg} / \mathrm{kg})$ to mice with LPS-induced thermal hyperalgesia did not produce significant changes compared to vehicle treated mice. However, both drugs showed a tendency to have some antinociceptive activity at 1 hour post treatment (increased percentage change in reaction latency after treatment compared to before treatment) in mice with LPS-induced thermal hyperalgesia (Figure 3B). The effects of indomethacin or minocycline compared to vehicle treatment were $31.4 \pm 10.9 \%$ and $43.2 \pm 16.0 \%$ increase in reaction latency time after treatment with minocycline or indomethacin, respectively, compared to $2.1 \pm 7.4 \%$ after vehicle treatment.
Coadministration of minocycline $50 \mathrm{mg} / \mathrm{kg}$ plus indomethacin $10 \mathrm{mg} / \mathrm{kg}$ to mice with LPS-induced hyperalgesia resulted in antinociceptive activity (Figure 3B). The effects of the combination treatment compared to vehicle treatment were significant at 1 hour post treatment $(61.9 \pm 20.3 \%$ in reaction latency time after treatment with minocycline plus indomethacin compared to $2.1 \pm 7.4 \%$ after vehicle treatment at 1 hour).

Effect of treatment with indomethacin, minocycline or coadministration of minocycline plus indomethacin in C57BL/6 mice with LPS-induced monoarthritis

Recently we reported that the Catwalk gait analysis system can be used to objectively quantify weight bearing changes and evaluate pharmacological antinociception in freely moving mice with LPS-induced monoarthritis [10].

Weight bearing changes were calculated using the ratio of right hind $(\mathrm{RH})$ limb to the left hind $(\mathrm{LH})$ limb paw pressure intensity (light intensity). The ratio of $\mathrm{RH} /$ LH paw print area were also measured.

The $\mathrm{RH} / \mathrm{LH}$ paw pressure ratio of the control group remained constant throughout the experiment, whereas

Table 3 Percentage of change from baseline reaction latency times of BALBc mice at 1 hour post-drug treatment with minocycline plus selective COX inhibitors in the hot plate test

\begin{tabular}{lc}
$\begin{array}{l}\text { Drug and dose administered to } \\
\text { mice }\end{array}$ & $\begin{array}{c}\text { \% Change in reaction latency (mean } \pm \text { S.E.M of the values obtained from } \mathbf{8} \text { to } \\
\mathbf{1 1} \text { animals.) }\end{array}$ \\
\hline $\begin{array}{l}\text { Vehicles (for COX inhibitors and } \\
\text { minocycline) }\end{array}$ & $\begin{array}{c}\text { Statistical } \\
\text { significance }\end{array}$ \\
\hline $\begin{array}{l}\text { selective COX-1 inhibitor, FR122047 } 10 \\
\text { mg/kg }\end{array}$ & $4.33 \pm 6.81(\mathrm{n}=11)$ \\
\hline $\begin{array}{l}\text { selective COX-2 inhibitor, CAY10404 } 10 \\
\text { mg/kg }\end{array}$ & $12.85 \pm 6.29(\mathrm{n}=8)$ \\
\hline \begin{tabular}{l} 
Minocycline 50 mg/kg \\
\hline FR122047 $10+$ minocycline $50 \mathrm{mg} / \mathrm{kg}$
\end{tabular} & $-26.34 \pm 3.35(\mathrm{n}=9)$ \\
\hline CAY10404 $10+$ minocycline $50 \mathrm{mg} / \mathrm{kg}$ & $-11.68 \pm 4.61(\mathrm{n}=11)$ \\
\hline
\end{tabular}

\# (response latency after drug treatment - baseline latency)/baseline latency $\times 100$.

${ }^{\S}$ Statistically significant differences in comparison with drug vehicle: ${ }^{* *} p<0.01$; ns: no statically significant differences in comparison with drug vehicle; statistically significant differences between minocycline alone and the combination of minocycline + selective COX inhibitor treatments: ${ }^{\#} p<0.01$; nz: no statically significant differences in comparison with minocycline alone (one-way ANOVA followed by Newman-Keuls test). 


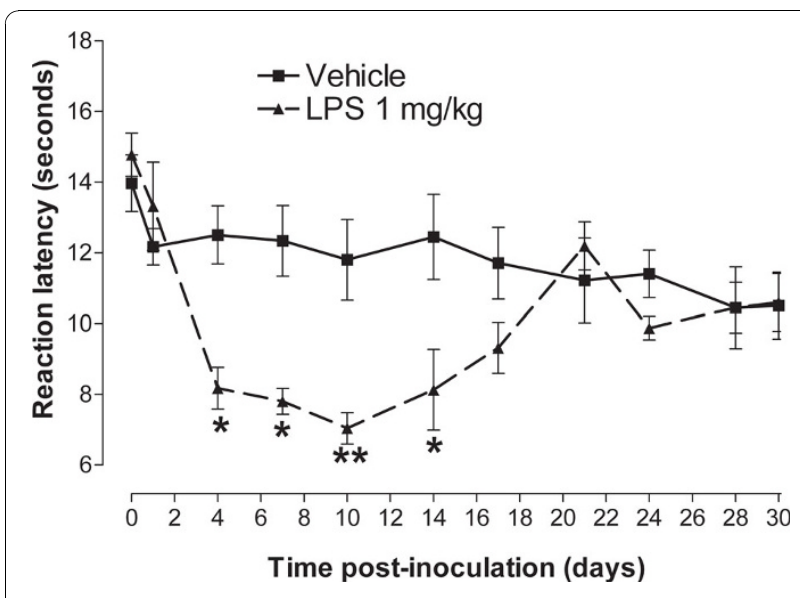

Figure 2 Lipopolysaccharide (LPS)-induces thermal hyperalgesia in BALB/c mice. Time course of the reaction latency time to the hot plate test after administration of LPS ( $1 \mathrm{mg} / \mathrm{kg}, \mathrm{n}=5$, i.p.) or its vehicle $(n=8)$. Each point represents the mean \pm S.E.M of the values obtained from 5-8 animals. Statistically significant differences in comparison with drug vehicle at the same time point post treatment: ${ }^{*} p<0.05$ and ** $p<0.01$ (two-way ANOVA followed by Bonferroni test).

those of LPS-inoculated mice decreased at 2 days after LPS administration compared to baseline or control mice $(\mathrm{p}<0.01$; Figure $4 \mathrm{~A}$ ) similar to what has been described previously [10].

The changes observed in paw print area ratios in LPS inoculated mice compared to solvent-injected controls were similar to those observed in paw pressure ratios. The $\mathrm{RH} / \mathrm{LH}$ print area ratio of the control group remained constant throughout the experiment, whereas those of LPS inoculated mice decreased at 2 days after LPS administration compared to baseline or control mice ( $\mathrm{p}<0.05$; Figure 4B).

We observed that a higher dose of indomethacin $(10 \mathrm{mg} / \mathrm{kg})$ can alleviate the weight bearing deficits in mice with LPS-induced monoarthritis (data not shown) as previously described [10]. Treatment of mice with LPS-induced monoarthritis using either indomethacin 1 $\mathrm{mg} / \mathrm{kg}$ or minocycline $50 \mathrm{mg} / \mathrm{kg}$ alone had no significant effect on the weight bearing or print area ratios deficits observed in these mice (Figure 4A,B). Mice with LPSinduced monoarthritis which were treated with the combination of minocycline $50 \mathrm{mg} / \mathrm{kg}$ plus indomethacin 1 $\mathrm{mg} / \mathrm{kg}$ had less weight bearing deficits and their $\mathrm{RH} / \mathrm{LH}$ paw pressure or print area ratios reverted to be similar to control animals, (no significant differences between control mice and those treated with the combination, Figure 4A,B). Coadministration of minocycline $50 \mathrm{mg} / \mathrm{kg}$ plus indomethacin $1 \mathrm{mg} / \mathrm{kg}$ to mice with LPS-induced monoarthritis significantly increased the $\mathrm{RH} / \mathrm{LH}$ paw pressure or print area at 1 hour post treatment by $34.5 \pm 12.3 \%$ and $85.8 \pm 23.8 \%$ respectively, compared to drug vehicle
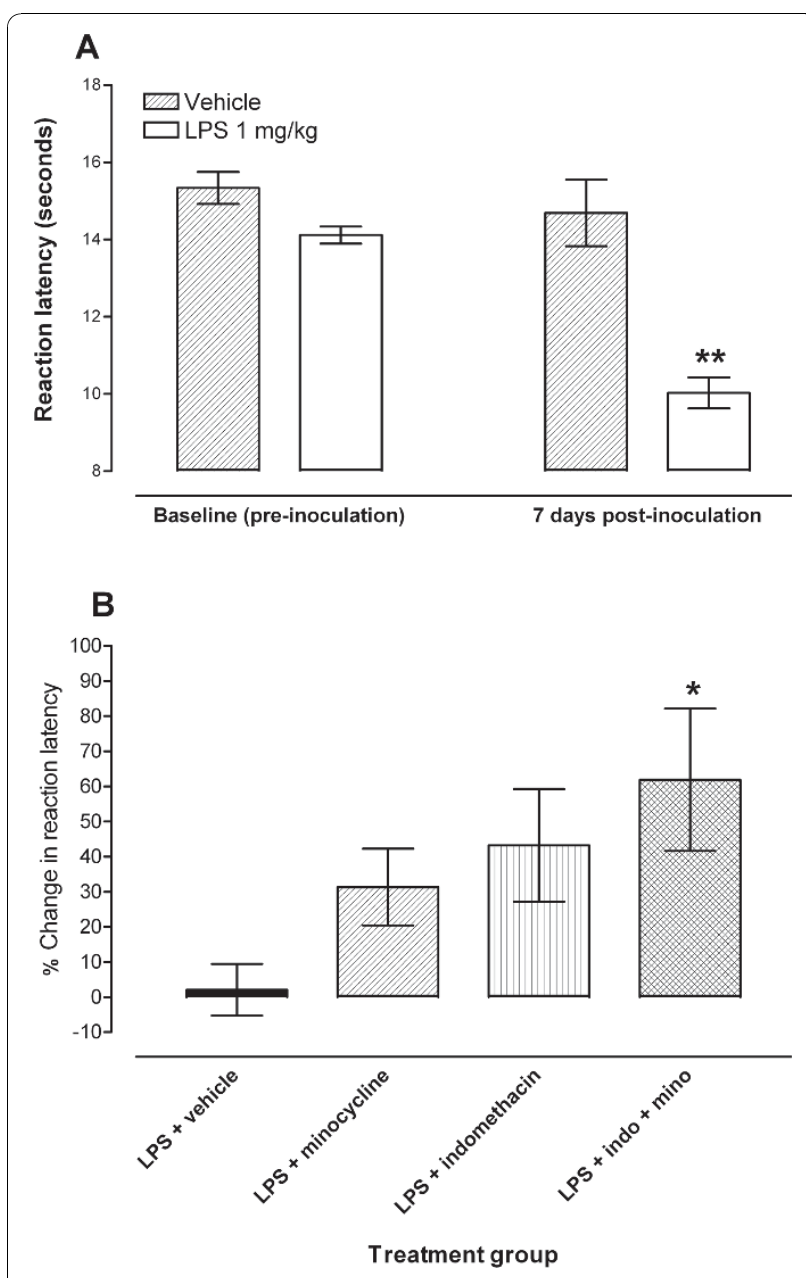

Figure 3 Coadministration of minocycline with indomethacin enhances their effects and alleviates LPS-induced hyperalgesia. Effect of treatment with indomethacin, minocycline or a combination of minocycline plus indomethacin on LPS-induced hyperalgesia at day 7 post lipopolysaccharide (LPS, $1 \mathrm{mg} / \mathrm{kg}$, i.p.) inoculation in a hot plate test in BALB/C mice. A: Hypernociceptive effects of LPS, $1 \mathrm{mg} / \mathrm{kg}$, i.p. in the hot plate model of inflammatory thermal hyperalgesia in BALB/C mice at 7 days post inoculation. Each point represents the mean \pm S.E.M of the values obtained from 6 vehicle-treated and 29 LPS-treated animals. Statistically significant differences in comparison with vehicle inoculated mice at the same time point post treatment: ${ }^{* *} p<0.01$ (two-way ANOVA followed by Bonferroni test). B: Percentage change in reaction latency times from baseline values (taken at 7 days post LPS) at 1 hour after treatment with minocycline (50 mg/kg, $\mathrm{n}=15)$, indomethacin $(10 \mathrm{mg} / \mathrm{kg}, \mathrm{n}=14)$, minocycline + indomethacin ( $\mathrm{n}=$ 16) or their vehicles $(n=12)$ in hot plate test. Each bar represents the mean \pm S.E.M of the values obtained from 12 to 16 animals. Statistically significant differences in comparison with drug vehicle: * $p<0.05$ (two-way ANOVA followed by Bonferroni test).

treated monoarthritic animals which had $-0.6 \pm 10.1 \%$ and $-5.4 \pm 23.7 \%$ change at 1 hour post treatment for $\mathrm{RH} / \mathrm{LH}$ paw pressure and print area respectively (Figure $4 C, D)$. The effects of coadministration of minocycline 


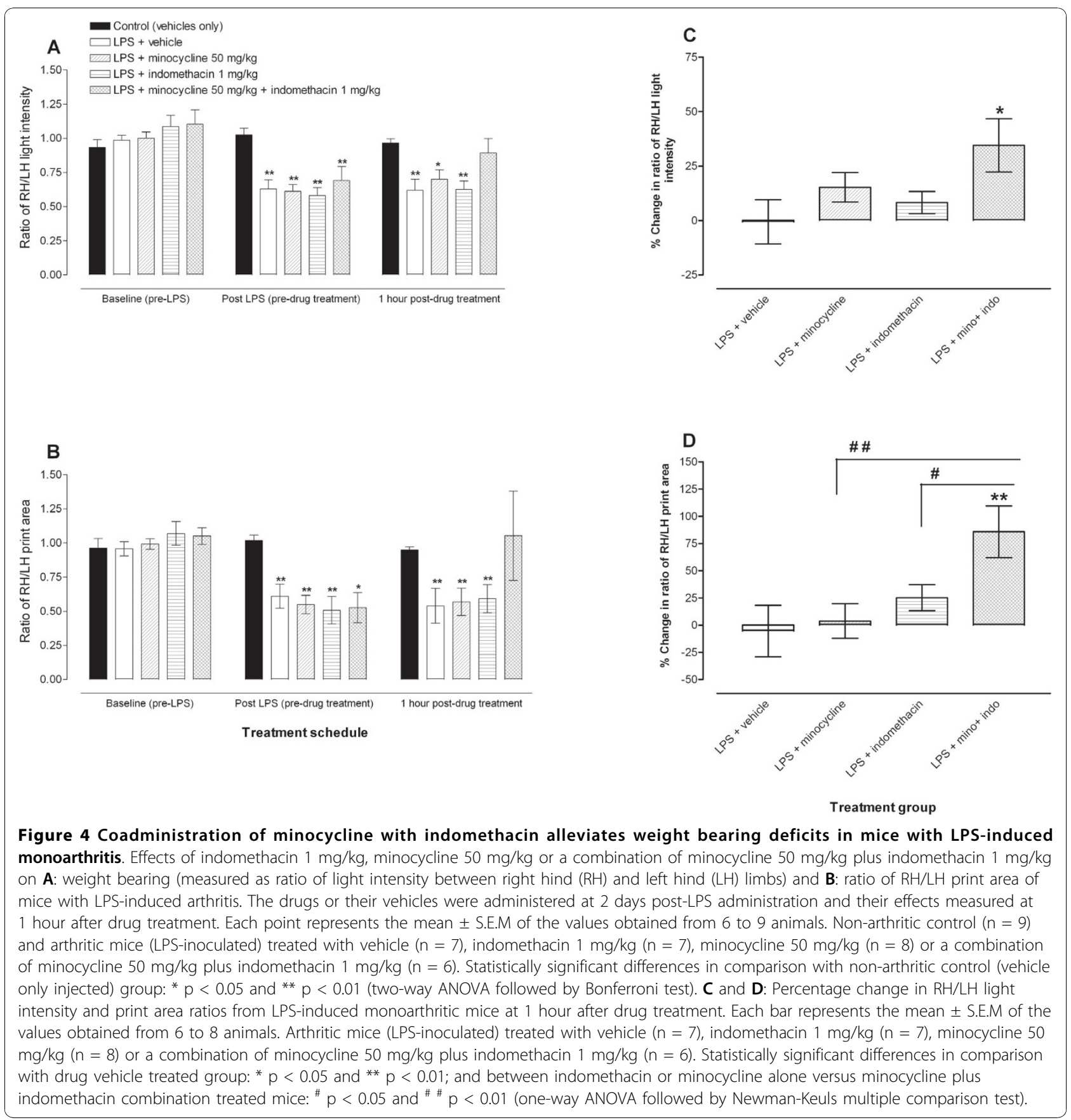

plus indomethacin on $\mathrm{RH} / \mathrm{LH}$ print area ratio was significantly higher than either indomethacin or minocycline treatment (Figure 4D).

\section{Discussion}

This is the first study to report enhanced antinociceptive activity and alleviation of weight bearing deficits by coadministering minocycline plus indomethacin, a NSAID, against thermal and arthritic nociception in mice.
The enhanced antinociceptive effects produced by coadministering minocycline plus indomethacin on inflammatory hyperalgesia and monoarthritis-induced weight bearing deficits could be useful in the management of inflammation and pain in patients with arthritis. Both drugs, minocycline and indomethacin, are used in the management of rheumatoid arthritis (RA) [1,5,21]. However, potentiation of each other's activities by the two compounds in alleviating pain and weight bearing deficits caused by inflammation or arthritis have not yet 
been reported. This potentiation of analgesic activity could have been missed in human RA because the interest on minocycline has been on its DMARD activity but not analgesic effects, moreover minocycline on its own even in our experimental setting does not have significant analgesic activity. It would be interesting to study in patients with arthritis whether co-administration of minocycline and indomethacin (or other NSAIDs) produce better analgesic activity than indomethacin or NSAIDs alone.

The LPS-induced hyperalgesia has been suggested to be due to the release and activation of pro-inflammatory cytokines and gelatinases, as well as glial cell activation [11-15]. Minocycline inhibits the synthesis and activity of gelatinases, the synthesis and release of cytokines as well a glial activation [7,38-42]. Thus some of the analgesic activities of minocycline observed in LPSinduced hyperalgesia but not in naïve animals could be due to its activities on cytokines, gelatinases and glial cells amongst other molecules and cells which are activated and involved in pain during inflammation.

We have previously observed that higher doses of indomethacin (10 $\mathrm{mg} / \mathrm{kg}$ and above) resulted in even load distribution between the arthritic right hind limb and the non-arthritic left hind limb in mice with LPSinduced arthritis similar to control animals without monoarthritis, using the Catwalk gait analysis method [10]. In the current study a lower dose of indomethacin $(1 \mathrm{mg} / \mathrm{kg}$ ) or minocycline at $50 \mathrm{mg} / \mathrm{kg}$ alone could not reverse the weight bearing deficits caused by monoarthritis, however, coadministration of minocycline $50 \mathrm{mg} / \mathrm{kg}$ with indomethacin at $1 \mathrm{mg} / \mathrm{kg}$ alleviated the weight bearing deficits induced by monoarthritis. The observed ability to restore weight bearing deficits has relevance to arthritis since patients with unilateral knee osteoarthritis transfer weight load from the arthritic leg to the hip and knee of the uninvolved leg; and relieving pain in the affected knee, results in even load distribution between the legs $[43,44]$.

Minocycline has anti-inflammatory activities and is used as a disease modifying antirheumatic drug. It has been reported to inhibit $\mathrm{T}$ cell activation, gletanisases and other matrix proteases activity and cytokine production in rheumatoid arthritis, thus reducing inflammation [45-48]. On the other hand indomethacin is purported to produce analgesia and anti-inflammatory activity through the inhibition of cycloxygenase and prostaglandin synthesis $[21,49]$. Since these drugs affect different targets, all involved in inflammation and pain during arthritis, coadministration could result in an enhancement of each other's activity and be more effective at lower doses.

Other possible reasons for the enhanced antinociceptive activity by coadministering minocycline and indomethacin could have been due to the inhibition of COX enzyme activity by indomethacin and inhibition of 5 -lipoxygenase activity by minocycline. The inhibition of COX-2 isoenzyme seems to be important for this synergism since coadministration of minocycline with CAY10404, a selective inhibitor of COX-2 [36] but not FR122047, a selective inhibitor of COX-1 [34,35], produced antinociceptive activity. Minocycline has been reported to block 5-lipoxygenase activation [50]. Recently, administration of a 5-lipoxygenase inhibitor has been reported to potentiate the antinociceptive activity of NSAIDs [51]. Thus, the 5-lipoxygenase inhibitory activity of minocycline could potentiate the activity of the NSAID, indomethacin. The other possible reason for the synergism on antinociception could be that the two drugs synergistically alter the endocannabinoid system in the central nervous system (CNS). Minocycline and indomethacin can both independently alter endocannabinoid levels or activity in the CNS and this has been linked to their antinociceptive activity $[52,53]$. Endocannabinoids have anti-inflammatory activities, antinociceptive activities and can reduce thermal hyperlagesia in rodents [54-56]. Possible biochemical pathways involved in minocycline and indomethacin enhancement of each other's antinociceptive activity warrants further research.

\section{Conclusions}

Using mice models of inflammation-induced thermal hyperalgesia and monoarthritis we show that coadministration of minocycline with indomethacin or a selective COX-2 inhibitor, CAY10404 potentiates their effects and results in antinociception against thermal nociception, reduction of thermal hyperalgesia and alleviation of weight bearing deficits in arthritic mice at doses where either drug alone has no significant activity. Thus, the combination of lower doses of a NSAID plus minocycline could be useful in the management of inflammatory pain and arthritis with less dose-dependent side effects.

\section{Authors' details}

Department of Applied Therapeutics, Faculty of Pharmacy, Kuwait University, P.O. Box 24923 Safat, 13110 Kuwait

\section{Abbreviations}

ANOVA: analysis of variance; CNS: central nervous system; i.p: intraperitoneally; LH: left hind limb; LPS: lipopolysaccharide; NSAID: nonsteroidal anti-inflammatory drug; PBS: phosphate buffered saline; $\mathrm{RH}$ : right hind limb; S.E.M: standard error of the mean

\section{Acknowledgements}

This study was supported by a grant from Kuwait University Research Administration (PT01/08). We are grateful to Dr Subramanian S Parvathy 
from the Department of Applied Therapeutics, Faculty of Pharmacy, Kuwait University, for her support and technical assistance.

\section{Authors' contributions}

AAA participated in the acquisition and analysis of data, and helped to edit the manuscript. WM participated in the design of the study, acquisition and analysis of data, and drafting and preparation of the manuscript. Both authors read and approved the final manuscript

\section{Competing interests}

The authors declare that they have no competing interests.

Received: 25 August 2010 Accepted: 1 December 2010

Published: 1 December 2010

\section{References}

1. Sapadin AN, Fleischmajer R: Tetracyclines: nonantibiotic properties and their clinical implications. J Am Acad Dermatol 2006, 54(2):258-265.

2. Kloppenburg M, Mattie H, Douwes N, Dijkmans BA, Breedveld FC Minocycline in the treatment of rheumatoid arthritis: relationship of serum concentrations to efficacy. J Rheumatol 1995, 22(4):611-616.

3. Langevitz P, Livneh A, Bank I, Pras M: Benefits and risks of minocycline in rheumatoid arthritis. Drug Saf 2000, 22(5):405-414.

4. Stone M, Fortin PR, Pacheco-Tena C, Inman RD: Should tetracycline treatment be used more extensively for rheumatoid arthritis? Metaanalysis demonstrates clinical benefit with reduction in disease activity. J Rheumatol 2003, 30(10):2112-2122.

5. Gaujoux-Viala C, Smolen JS, Landewe R, Dougados M, Kvien TK, Mola EM, Scholte-Voshaar M, van Riel P, Gossec L: Current evidence for the management of rheumatoid arthritis with synthetic disease-modifying antirheumatic drugs: a systematic literature review informing the EULAR recommendations for the management of rheumatoid arthritis. Ann Rheum Dis 2010, 69(6):1004-1009.

6. Mika J, Osikowicz M, Makuch W, Przewlocka B: Minocycline and pentoxifylline attenuate allodynia and hyperalgesia and potentiate the effects of morphine in rat and mouse models of neuropathic pain. Eur J Pharmacol 2007, 560(2-3):142-149.

7. Raghavendra V, Tanga F, DeLeo JA: Inhibition of microglial activation attenuates the development but not existing hypersensitivity in a rat model of neuropathy. J Pharmacol Exp Ther 2003, 306(2):624-630.

8. Bastos LF, Merlo LA, Rocha LT, Coelho MM: Characterization of the antinociceptive and anti-inflammatory activities of doxycycline and minocycline in different experimental models. Eur J Pharmacol 2007, 576(1-3):171-179.

9. Chen WT, Mahmood U, Weissleder R, Tung CH: Arthritis imaging using a near-infrared fluorescence folate-targeted probe. Arthritis Res Ther 2005, 7(2):R310-317.

10. Masocha W, Parvathy SS: Assessment of weight bearing changes and pharmacological antinociception in mice with LPS-induced monoarthritis using the Catwalk gait analysis system. Life Sci 2009, 85(11-12):462-469.

11. Cunha FQ, Poole S, Lorenzetti BB, Ferreira SH: The pivotal role of tumour necrosis factor alpha in the development of inflammatory hyperalgesia. BrJ Pharmacol 1992, 107(3):660-664.

12. Cunha TM, Verri WA Jr, Fukada SY, Guerrero AT, Santodomingo-Garzon T, Poole S, Parada CA, Ferreira SH, Cunha FQ: TNF-alpha and IL-1 beta mediate inflammatory hypernociception in mice triggered by $\mathrm{B} 1$ but not B2 kinin receptor. Eur J Pharmacol 2007, 573(1-3):221-229.

13. Ferreira SH, Lorenzetti BB, Poole S: Bradykinin initiates cytokine-mediated inflammatory hyperalgesia. Br J Pharmacol 1993, 110(3):1227-1231.

14. Guo LH, Schluesener HJ: Acute but not chronic stimulation of glial cells in rat spinal cord by systemic injection of lipopolysaccharide is associated with hyperalgesia. Acta Neuropathol 2006, 112(6):703-713.

15. Talhouk RS, Hajjar L, Abou-Gergi R, Simaa'n CJ, Mouneimne G, Saade NE, Safieh-Garabedian B: Functional interplay between gelatinases and hyperalgesia in endotoxin-induced localized inflammatory pain. Pain 2000, 84(2-3):397-405.

16. Sachs D, Cunha FQ, Poole S, Ferreira SH: Tumour necrosis factor-alpha, interleukin-1 beta and interleukin-8 induce persistent mechanical nociceptor hypersensitivity. Pain 2002, 96(1-2):89-97.
17. Poole S, Lorenzetti BB, Cunha JM, Cunha FQ, Ferreira SH: Bradykinin B1 and $B 2$ receptors, tumour necrosis factor alpha and inflammatory hyperalgesia. Br J Pharmacol 1999, 126(3):649-656.

18. Nakamura M, Ferreira SH: A peripheral sympathetic component in inflammatory hyperalgesia. Eur J Pharmacol 1987, 135(2):145-153.

19. Inoue A, Ikoma K, Morioka N, Kumagai K, Hashimoto T, Hide I, Nakata Y: Interleukin-1 beta induces substance $P$ release from primary afferent neurons through the cyclooxygenase-2 system. J Neurochem 1999, 73(5):2206-2213.

20. Dougados M: The role of anti-inflammatory drugs in the treatment of osteoarthritis: a European viewpoint. Clin Exp Rheumatol 2001, 19(6 Suppl 25):S9-14.

21. Daoud KF, Jackson CG, Williams HJ: Basic therapy for rheumatoid arthritis: nonsteroidal anti-inflammatory drugs. Compr Ther 1999, 25(8-10):427-433.

22. Cronstein BN, Terkeltaub $R$ : The inflammatory process of gout and its treatment. Arthritis Res Ther 2006, 8(Suppl 1):S3.

23. Yunus MB: Current therapeutic practices in spondyloarthropathies. Compr Ther 1988, 14(2):54-64.

24. Vane J, Botting R: Inflammation and the mechanism of action of antiinflammatory drugs. Faseb J 1987, 1(2):89-96.

25. Mitchell JA, Warner TD: Cyclo-oxygenase-2: pharmacology, physiology, biochemistry and relevance to NSAID therapy. Br J Pharmacol 1999, 128(6):1121-1132.

26. Ferreira SH: Peripheral analgesic sites of action of anti-inflammatory drugs. Int I Clin Pract Suppl 2002, , 128: 2-10.

27. Suleyman H, Demircan B, Karagoz Y: Anti-inflammatory and side effects of cyclooxygenase inhibitors. Pharmacol Rep 2007, 59(3):247-258.

28. McCormack K: The spinal actions of nonsteroidal anti-inflammatory drugs and the dissociation between their anti-inflammatory and analgesic effects. Drugs 1994, 47(Suppl 5):28-45, discussion 46-27.

29. Pini LA, Sandrini $M$, Vitale G: Involvement of brain serotonergic system in the antinociceptive action of acetylsalicylic acid in the rat. Inflamm Res 1995, 44(1):30-35.

30. Bjorkman R: Central antinociceptive effects of non-steroidal antiinflammatory drugs and paracetamol. Experimental studies in the rat. Acta Anaesthesiol Scand Suppl 1995, 103:1-44.

31. Sandrini M, Vitale G, Pini LA: Effect of rofecoxib on nociception and the serotonin system in the rat brain. Inflamm Res 2002, 51(3):154-159.

32. Hamza M, Dionne RA: Mechanisms of non-opioid analgesics beyond cyclooxygenase enzyme inhibition. Curr Mol Pharmacol 2009, 2(1):1-14

33. Zimmermann M: Ethical guidelines for investigations of experimental pain in conscious animals. Pain 1983, 16(2):109-110.

34. Ochi T, Motoyama Y, Goto T: The analgesic effect profile of FR122047, a selective cyclooxygenase-1 inhibitor, in chemical nociceptive models. Eur J Pharmacol 2000, 391(1-2):49-54.

35. Wibberley A, McCafferty GP, Evans C, Edwards RM, Hieble JP: Dual, but not selective, COX-1 and COX-2 inhibitors, attenuate acetic acid-evoked bladder irritation in the anaesthetised female cat. Br J Pharmacol 2006, 148(2):154-161.

36. Habeeb AG, Rao PNP, Knaus EE: Design and syntheses of diarylisoxazoles: novel inhibitors of cyclooxygenase-2 (COX-2) with analgesicantiinflammatory activity. Drug Dev Res 2000, 51:273-286.

37. Hamers FP, Lankhorst AJ, van Laar TJ, Veldhuis WB, Gispen WH: Automated quantitative gait analysis during overground locomotion in the rat: its application to spinal cord contusion and transection injuries. $J$ Neurotrauma 2001, 18(2):187-201.

38. Tikka T, Fiebich BL, Goldsteins G, Keinanen R, Koistinaho J: Minocycline, a tetracycline derivative, is neuroprotective against excitotoxicity by inhibiting activation and proliferation of microglia. J Neurosci 2001, 21(8):2580-2588

39. Masocha W, Rottenberg ME, Kristensson K: Minocycline impedes African trypanosome invasion of the brain in a murine model. Antimicrob Agents Chemother 2006, 50(5):1798-1804.

40. Ryan ME, Usman A, Ramamurthy NS, Golub LM, Greenwald RA: Excessive matrix metalloproteinase activity in diabetes: inhibition by tetracycline analogues with zinc reactivity. Curr Med Chem 2001, 8(3):305-316.

41. Paemen L, Martens E, Norga K, Masure S, Roets E, Hoogmartens J, Opdenakker G: The gelatinase inhibitory activity of tetracyclines and chemically modified tetracycline analogues as measured by a novel microtiter assay for inhibitors. Biochem Pharmacol 1996, 52(1):105-111. 
42. Kim SS, Kong PJ, Kim BS, Sheen DH, Nam SY, Chun W: Inhibitory action of minocycline on lipopolysaccharide-induced release of nitric oxide and prostaglandin E2 in BV2 microglial cells. Arch Pharm Res 2004, 27(3):314-318.

43. Olsson E, Goldie I, Wykman A: Total hip replacement. A comparison between cemented (Charnley) and non-cemented (HP Garches) fixation by clinical assessment and objective gait analysis. Scand J Rehabil Med 1986, 18(3):107-116.

44. Weidenhielm L, Svensson OK, Brostrom Lk L: Surgical correction of leg alignment in unilateral knee osteoarthrosis reduces the load on the hip and knee joint bilaterally. Clin Biomech (Bristol, Avon) 1995, 10(4):217-221.

45. Kloppenburg M, Verweij CL, Miltenburg AM, Verhoeven AJ, Daha MR, Dijkmans BA, Breedveld FC: The influence of tetracyclines on T cell activation. Clin Exp Immunol 1995, 102(3):635-641.

46. Sewell KL, Breedveld F, Furrie E, O'Brien J, Brinckerhoff C, DynesiusTrentham R, Nosaka Y, Trentham DE: The effect of minocycline in rat models of inflammatory arthritis: correlation of arthritis suppression with enhanced T cell calcium flux. Cell Immunol 1996, 167(2):195-204.

47. Tilley BC, Alarcon GS, Heyse SP, Trentham DE, Neuner R, Kaplan DA, Clegg DO, Leisen JC, Buckley L, Cooper SM, et al: Minocycline in rheumatoid arthritis. A 48-week, double-blind, placebo-controlled trial. MIRA Trial Group. Ann Intern Med 1995, 122(2):81-89.

48. Cooper SM: A perspective on the use of minocycline for rheumatoid arthritis. J Clin Rheumatol 1999, 5(4):233-237, discussion 237-238.

49. Daymond TJ, Rowell FJ: Reduction of prostaglandin E2 concentrations in synovial fluid of patients suffering from rheumatoid arthritis following tiaprofenic acid or indomethacin treatment. Drugs 1988, 35(Suppl 1):4-8.

50. Song Y, Wei EQ, Zhang WP, Zhang L, Liu JR, Chen Z: Minocycline protects PC12 cells from ischemic-like injury and inhibits 5-lipoxygenase activation. Neuroreport 2004, 15(14):2181-2184

51. Bishnoi M, Patil CS, Kumar A, Kulkarni SK: Potentiation of antinociceptive effect of NSAIDs by a specific lipooxygenase inhibitor, acetyl 11-ketobeta boswellic acid. Indian J Exp Biol 2006, 44(2):128-132.

52. Guasti L, Richardson D, Jhaveri M, Eldeeb K, Barrett D, Elphick MR, Alexander SP, Kendall D, Michael GJ, Chapman V: Minocycline treatment inhibits microglial activation and alters spinal levels of endocannabinoids in a rat model of neuropathic pain. Mol Pain 2009, 5:35.

53. Guhring $H$, Hamza M, Sergejeva M, Ates M, Kotalla CE, Ledent C, Brune K: A role for endocannabinoids in indomethacin-induced spinal antinociception. Eur J Pharmacol 2002, 454(2-3):153-163.

54. Richardson JD, Kilo S, Hargreaves KM: Cannabinoids reduce hyperalgesia and inflammation via interaction with peripheral CB1 receptors. Pain 1998, 75(1):111-119.

55. Calignano A, La Rana G, Piomelli D: Antinociceptive activity of the endogenous fatty acid amide, palmitylethanolamide. Eur J Pharmacol 2001, 419(2-3):191-198.

56. Chen L, Zhang J, Li F, Qiu Y, Wang L, Li YH, Shi J, Pan HL, Li M: Endogenous anandamide and cannabinoid receptor-2 contribute to electroacupuncture analgesia in rats. J Pain 2009, 10(7):732-739.

\section{Pre-publication history}

The pre-publication history for this paper can be accessed here: http://www.biomedcentral.com/1471-2474/11/276/prepub

\section{doi:10.1186/1471-2474-11-276}

Cite this article as: Abu-Ghefreh and Masocha: Enhancement of antinociception by coadminstration of minocycline and a non-steroidal anti-inflammatory drug indomethacin in naive mice and murine models of LPS-induced thermal hyperalgesia and monoarthritis. BMC

Musculoskeletal Disorders 2010 11:276.

\section{Submit your next manuscript to BioMed Central and take full advantage of:}

- Convenient online submission

- Thorough peer review

- No space constraints or color figure charges

- Immediate publication on acceptance

- Inclusion in PubMed, CAS, Scopus and Google Scholar

- Research which is freely available for redistribution 